\title{
3 Quality of Life Convergence in the EU: Do Eastern and Southern European States Lag Behind?
}

\author{
Panagiotis Liargovas and Stavroula Kratimenou ${ }^{10}$
}

\begin{abstract}
Currently, there is renewed interest for convergence process in the EU. According to the EU Five Presidents' Report, convergence towards more resilient economic and social structures in Member States is an essential element for the successful performance of EMU in the long run. The purpose of this paper is twofold: First, to investigate convergence between the countries of the European Union (EU28), as well as the evolution of inequalities in the period 1990 to 2015, with more emphasis in Eastern and Southern Europe. Second, to use Quality of Life indicators in the empirical analysis. It measures convergence or divergence of the $28 \mathrm{EU}$ membercountries using two complementary approaches, the first based on coefficient of variation and the second based on the values of a composite index of Quality of Life for each EU Member-State. This exercise will be useful in drawing lessons from the successes and failures of cohesion policy in the Eastern, South Eastern, and Southern periphery. It is also a useful tool for EU policy-makers.
\end{abstract}

Keywords: Disparities, Quality of Life Indices, Convergence

\subsection{Introduction}

The empirical assessment of convergence is controversial. Most of the controversy has centred on the level of convergence-i.e. between regions or between countries. In both cases, the more rigorous analyses of convergence have tended to focus on economic phenomena, neglecting social and quality of life phenomena. However, comparisons of quality of life between nations have received special attention, because of their all-inclusive nature, which focuses on region-specific amenities. The contention is that individual well being, depends upon quality of life factors such as infrastructure, environmental quality, healthcare, crime rates and public services, as well as the more traditional pecuniary factors such as money income and the prices of goods, which determine cost of living.

Only a few studies have analysed the convergence of countries in terms of a set of quality-of-life variables, such as Giannias, Liargovas, \& Manolas, (1999) for Europe; Hobijn \& Franses, (2001) and Mazumdar (2003) in a wider international

10 University of Peloponnese, Jean Monnet Center of Excellence; End Karaiskaki Street, Tripoli 22100, Greece. Correspondence: liargova@uop.gr

Ә Open Access. (c) 2020 Ida Musiałkowska, Piotr Idczak, Oto Potluka and chapters' contributors. Published by De Gruyter. (c) BY-NC-ND This work is licensed under the Creative Commons Attribution-NonCommercial-NoDerivs 3.0 License. https://doi.org/10.1515/9788395720451-004 
framework; E O’Leary (2001) for Ireland; Marchante, Ortega and Sánchez (2006) for Spain; Liargovas and Fotopoulos (2008) for Greece; Royuela and García (2015) for Colombia, and Royuela and Artís (2006) for Barcelona. Finally, the local scope is much less analysed in the literature: O'Donoghue, (2000) analyses the convergence of employment structures in the British urban system; Royuela and Artís (2006) for Barcelona, and Pack (2004) studies the determinants of regional growth and its determinants jointly with the existence of convergence across US Metropolitan areas.

The purpose of this paper is twofold: First, to investigate convergence between the countries of the European Union (EU-28), as well as the evolution of inequalities in the period between 1990 to 2015, with more emphasis on Eastern and Southern Europe. Second, to use Quality of Life indicators in our empirical analysis. We measure real convergence or divergence of the $28 \mathrm{EU}$ member countries using two complementary approaches, the first based on coefficient of variation and the second based on the values of a composite index of Quality of Life for each EU member-state. Our proposed methodology has three main advantages: Firstly, it focuses on real convergence, which is convergence beyond per capita income that takes into account various aspects of the quality of life. Secondly, it uses a simple and robust measure of convergence, the coefficient of variation. It is beyond the scope of this paper to use sophisticated methodologies of convergence (e.g. Bunyaratavej \& Hahn, 2005). Rather, we try to apply a simple method of convergence on Quality of Life indices. Finally, we construct a composite Quality of Life index to observe disparities between EU countries and their evolution over time. Based on these results, country rankings can be determined. This exercise allows us to make an assessment of the effectiveness of cohesion policy in the Eastern, South Eastern and Southern periphery. Policy makers have shown a great concern for the variations in the economic and social performance of the different EU Member States in recent years.

The preamble of the Treaty of Rome calls for a reduction of the "differences existing between the various regions and the backwardness of the less favored regions", while Article 2 of the Treaty refers to the goal of "harmonious development, of economic activities, a continuous and balanced expansion". ${ }^{11}$ With respect to regional equality and convergence, the EU cohesion policy is a key policy area. This policy is the second biggest policy field in the EU and also represents a significant portion of the budget. Cohesion and structural funds comprise almost a third of the total EU budget. In the current programme period of 2014-2020, budget allocation was 351.8 billion euros.

The second section of this study discusses the measures of convergence and investigates the evolution of relative inequalities between countries within the identified convergence or divergence process. The third section presents the empirical results and discusses some possible explanations behind observed patterns. A final section offers some conclusions.

11 See https://ec.europa.eu/romania/sites/romania/files/tratatul_de_la_roma.pdf 


\subsection{The Concept of Quality of Life: Selecting Indicators}

Giving a precise definition of the concept of Quality of Life is far from easy. The notion is highly intuitive for the population at large. Yet, from a scientific standpoint, it proves extremely difficult to detail in essence. The problem is further complicated when considering that Quality of Life is closely linked to other related concepts, such as standard of living, or wellbeing. By way of an initial approach, it can be said that Quality of Life is the substantive element, whilst standard of living is the situation in which Quality of Life finds itself at a given moment; wellbeing is the consequence of the two previously mentioned concepts. Thus, Quality of Life may be deemed as stock, while standard of living and wellbeing are fluxes that require a complex measuring process. Although no exact definition is required for the purpose of the present study, it does seem appropriate to choose a useful definition that can bring us as close as possible to the concept. In this vein, and as a result of the research conducted by authors of this present work, we adopt the following definition:

Quality of life is the result of complex interactions of a set of objective and subjective factors: objective factors refer to external conditions of an economic, sociopolitical, environmental, and cultural nature, while subjective factors refer to individuals' perception of their own life and the satisfaction reached in its various dimensions.

(Somarriba, 2008)

The above definition refers to both objective and subjective factors as integral parts of the concept under scrutiny. Choosing such a definition with the goal of measuring the concept of Quality of Life thus entails determining what these factors are, and selecting and constructing a system of indicators which serve to gauge Quality of Life in the various EU countries from a time-related perspective.

Our concept of Quality of Life quality of life is similar to the one found in European Surveys, carried out every four years. These surveys examine both the objective circumstances of European citizens' lives and how they feel about those circumstances and their lives in general. They look at a range of issues, such as employment, income, education (Pinquart \& Sörensen, 2000), housing, family, health and work-life balance (Von Dem Knesebeck et al., 2007). They also look at subjective topics, such as people's levels of happiness, how satisfied they are with their lives, and how they perceive the quality of their societies. Our own concept of Quality of Life quality distinguishes between five main levels: 1) Population Density; 2) Economy and Development; 3) Services; 4) Natural and Urban Environment, and 5) Infrastructure, which are delineated in the following subsections. Data were taken from World Bank. ${ }^{12}$

12 See http://documents.worldbank.org/curated/en/462341468766204683/World-developmentindicators-2000 


\subsubsection{Population Density}

Population density is defined as the number of people per unit area (usually per square kilometre) and occasionally refers to the geographical boundaries of a city, a country, or the entire globe. The importance of this indicator is significant because knowledge of the population density in a region and the monitoring of its evolution contribute significantly to various sectors. As the population density increases, so do the environmental pressures and the quality of life of the overall population of the study area. Among other things, subsequent to the increase of population density is the increase in requirements for logistics infrastructure (schools, hospitals, residences... etc.), the need for infrastructure (electricity, water and telecommunications networks), increased traffic load and intensity, lack of parking space, greater and more intensive need for cleanliness and care to reduce pollutants of all kinds, and the need for new jobs (increasing unemployment rates). The indicator is an indirect measurement of the environmental pressure and includes the exploitation of natural resources as well as the pollution of air and water.

\subsubsection{Economy \& Development}

Economic growth is central and essential for a country's economic development. As the national income grows, people benefit. A country's economic development undoubtedly leads to the improvement of its quality of life and people are more satisfied in their everyday-lives. Since there is no formula for stimulating economic growth, data can help policymakers further understand their country's economic situation to guide any work towards improvement. In terms of economic growth, we include indices that reflect economic growth, equity, consumption, employment, savings, government spending, imports/exports. In this study, we focus on Gross Domestic Product (GDP) per capita, long-term unemployment, final consumption expenditure, and electric power consumption (kWh per capita).

\subsubsection{GDP Per Capita}

Socio-economic indicators are undoubtedly the focus of interest in any study on quality of life. It helps identify the possibilities that individuals have in order to improve their standard of living. In general, the main socio-economic indicators include income, housing, employment and consumption. Of these, income is an important factor in the quality of life, because it determines the personal financial situation. Income per capita is the average income for each resident, regardless of his/her/their participation in the production process. The level of income per capita is the most important criterion for the standard of people's living. The main index that reflects 
the income situation of residents of an area, and subsequently used in this study, is gross domestic product per capita (GDP). GDP per capita is the sum of the value of the final products, produced by society in a given time. It includes all the incomes of the spatial unit of measurement, even of foreigners, but excludes the salaries and profits earned by citizens from sources outside the specified time unit. The advantage of GDP is that includes the entire economic activity for the area being studied. The limitations of the indicator, on the contrary, are its complexity and that it is based on statistical data, which must be reliable. Even so, this is often underestimated by developing countries, due to self-consumption, domestic work and informal economy trends. It also gives a rough account of the level of development of a country in matters relating to the distribution of wealth, but also of individual characteristics such as education, health... etc.

\subsubsection{Long-Term Unemployment}

The existence of unemployment corresponds with reduced initial resources and, consequently, to the deterioration of the quality of life. Accurate plotting of the importance of employment long-term unemployment rates are used. Long-term unemployment refers to the number of people with continuous unemployment for a period of one year or more, expressed as a percentage of the total unemployed. The long-term unemployment rate is an index showing the economic level and the quality of life within a country. Long-term unemployment is widely considered to be the basic cause of poverty. Moreover, in times of prolonged recession, the social cost of unemployment is further magnified by increasing crime and violence, the crisis of institutions, and the general decline of social cohesion. The deprivation of the right to work undermines confidence in the state and encourages indifference to political and social events. Unemployment has always been the most important problem in modern economies of capitalist systems. Even if an economy rebounds, because of GDP, it does not meet its citizens' demands, where there is a high proportion of unemployed, especially in the youth population. This is because unemployment has serious repercussions and effects on those who are unemployed and have no source of income. In addition, unemployment means a loss of productive labour, the most important factor in a modern economy, which means a further reduction in demand, and therefore the variety of products produced and offered in an economy.

\subsubsection{Household Consumption Expenditure per Capita \& Electric Power Consumption}

For the determination of consumer expenditure, we use final household consumption expenditure (per capita) and the electric power consumption (kWh per capita) as indicators. Final consumption expenditure is the market value of all goods and 
services, including durable products (such as cars, washing machines, and home computers), purchased by households.

\subsubsection{Services}

A person's quality of life depends on available services that exist in each country between EU-28, which meet basic needs. It should be noted however, that the range of services among the countries of the European Union is not homogeneous. There are significant differences between them. It is appropriate to use a large number of indicators to describe the services of an area. The most important areas in this respect are the sector of health, education, transport, communications, security, and culture.

\subsubsection{Health}

Health is an essential element of the quality of life of a country's citizens. Poor health can affect the overall progress of society, as well as the subjective wellbeing of individuals. Improving health is vital for the Millennium Development Goals ${ }^{13}$ and the public sector is a major provider of healthcare in developing countries. Sanitary protection and medical care are vital inputs to ensure the health of residents of a country. With the main goal of reducing inequality, many countries have focused on primary healthcare, including immunization, sanitation, access to safe drinking water, and safe motherhood initiatives. In the present work, the indices that are used to carry out the conclusions in the health sector are:

The first index is (a) Life Expectancy. Life expectancy is the number of years a person is expected to live, starting from birth (life expectancy at birth). A widely used index of population health, life expectancy measures the quantity rather than quality of life. The significance of the index: Life expectancy at birth reflects the overall mortality rate of the population. It summarizes the evolution of mortality among all age groups - children and adolescents, adults and the elderly. In addition, the data on healthy life years-or life expectancy without disabilities-indicates the number of years that a person of a certain age is expected to live without disabilities. The Healthy Life Year Index is at the heart of the European Structural Indicators, as its importance is recognized in the Treaty of Lisbon. The index is used to monitor health as a factor of productivity/economy, introducing the concept of quality of life, measuring the

13 The eight Millennium Development Goals (MDGs) - which range from halving extreme poverty rates to halting the spread of HIV/AIDS and providing universal primary education, all by the target date of 2015 - form a blueprint agreed to by all the world's countries and all the world's leading development institutions. See https://www.un.org/millenniumgoals/. 
employability of older workers, as well as monitoring the progress made in terms of quality and sustainability of healthcare and access to it. The second index is (b) the number of doctors per 1000 physicians (per 1,000 people). This includes general and qualified doctors, and a mortality rate under five (5) years (per 1,000 live births), which shows the probability that in 1,000 births, a new-born baby will die before the age of five.

\subsubsection{Education}

In all economies, education plays a vital role in the progress of citizens' lives. Education levels may determine the profession of each person. People with limited capabilities and skills are often excluded from a wide range of jobs, sometimes missing opportunities to achieve remarkable goals within society. Such citizens may also have fewer prospects for economic prosperity. In Europe, education indices that are important for quality of life are: the educational level of the population, the number of people enrolled in primary and secondary education, the number of early school dropouts, self-estimation, as well as lifelong learning. Education is one of the most powerful means to reduce poverty and inequality between countries. It sets the foundations for sustainable economic growth.

The indices used in this survey on the education sector are: (a) the percentage of primary school enrolment, irrespective of age, expressed as a percentage of the total population. This indicator may be over $100 \%$ due to the inclusion of primary overaged or under-aged pupils in primary education, given their early or late entry into the primary education system. Second, (b) the percentage of secondary education school enrolment, which corresponds to the total enrolment in secondary education, irrespective of age, and expressed as the percentage of the total population from the official age of the secondary school education. This index may also exceed $100 \%$ due to the inclusion of over-aged or under-aged students in secondary education.

\subsubsection{Natural \& Urban Environment}

Environmental protection has been very important on the European agenda over the last decades. The overwhelming majority of European citizens believe that environmental protection is imperative with significant impact on people's quality of life. Exposure to air, noise pollution, and water pollution can have a direct impact on the health of citizens and the economic wellbeing of communities. Environmental indicators are very important for assessing the quality of life not only in Europe, but also in the rest of the world. In most studies, environmental indices determine the amount of environmental damage done by factors such as pollution, $\mathrm{CO}_{2}$ emissions... 
etc. Environmental indices also include quantitative surveys on the quality of open land, water areas, and indicators associated with the climate.

In this paper the indices used are: First, (a) Carbon dioxide $\left(\mathrm{CO}_{2}\right)$ emissions (metric tonnes per capita). It is an index that measures carbon dioxide emissions from fossil fuel combustion and cement production. $\mathrm{CO}_{2}$ is now known as greenhouse gas. $\mathrm{CO}_{2}$ emission comes from human activity, ultimately creating a phenomenon known as climate change, i.e. the long-term alteration in earth's climate and weather patterns. Nowadays, a great deal of effort is being made to reduce global $\mathrm{CO}_{2}$ emissions. Carbon footprint measurement is a common practice for many organizations worldwide and is usually accompanied by a specific climate change strategy. Second, (b) the index that reflects forest area ( $\%$ of land area) refers to tree clusters, located in urban parks or gardens, with the exception of those trees belonging to agricultural production systems (for example, fruit plantations and agro-forestry systems).

\subsubsection{Infrastructure}

Infrastructure helps the success of production and agricultural activities. Investment in areas such as water, sanitation, energy, housing, and transport help reduce poverty. New electronic and communication technologies also promote growth, improve health services, extend learning opportunities, and support social and cultural developments. Information is an indispensable element for access to physical and intangible resources that belong to the infrastructure sector. The index used involve cellular mobile telephone subscriptions/devices per 100 people, as well as the number of Internet users per 100 people. Mobile-phone subscriptions refer to the number of subscriptions to public cellular network services that provide access to the Public Switched Telephone Network (PSTN) using cellular technology. The index includes the number of subscription contracts and the number of active prepaid accounts (i.e. lines used within three months). The index applies to all mobile subscriptions that offer voice communications. It excludes subscriptions via data cards or USB modems, subscriptions to public mobile data services, private flip-flop mobile telephony, Teletext, radiotelephone, and telemetry services. This index is calculated as the number of mobile-phone subscriptions divided by the population and multiplied by 100 .

Another index is the number of Internet users per 100 people. Over the last decade, the Internet has changed the way people work, retrieve information, and communicate. Today there is hardly an aspect of human life not mediated by the flow of available information on the hundreds of millions of websites that make up the internet, and of course its affordance to keep people in touch with one another through technologies such as e-mail (Henderson, 2001). The Internet has the ability to connect people to each other, simplify their lives, and make it easier in many ways. So at the dawn of the 21st century, it plays an important role in the perception of people's 
quality of life. According to the World Bank, ${ }^{14}$ Internet users are made up of people who have access to the Internet. Analysing the data from the World Bank shows that in 1990, the number of Internet users was insignificant. For example, although Sweden occupies first place in the quality of life Index, the percentage of online users was just 0.5841 in 1990 (see Table 3).

Table 1: Indices Quality Of Life.

\begin{tabular}{ll}
\hline Index & Source \\
\hline Population density (people per sq. km of land area) & World Bank Group 2000 \\
GDP per capita (current US\$) & World Bank Group 2000 \\
Electric power consumption (kWh per capita) & World Bank Group 2000 \\
Long-term unemployment & World Bank Group 2000 \\
$\begin{array}{l}\text { Household final consumption expenditure per capita } \\
\text { (constant 2005 US\$) }\end{array}$ & World Bank Group 2000 \\
Mortality rate, under-5 (per 1.000 live births) & World Bank Group 2000 \\
Physicians (per 1.000 people) & World Bank Group 2000 \\
Life expectancy at birth, total (years) & World Bank Group 2000 \\
School enrolment, primary (\% gross) & World Bank Group 2000 \\
School enrolment, secondary (\% gross) & World Bank Group 2000 \\
CO2 emissions (metric tons per capita) & World Bank Group 2000 \\
Internet users (per 100 people) & World Bank Group 2000 \\
\hline & World Bank Group 2000 \\
\hline
\end{tabular}

Source: Own elaboration

14 See http://documents.worldbank.org/curated/en/462341468766204683/World-developmentindicators-2000 


\subsection{Measuring Convergence}

In this research the evolution of inequalities between EU-28 is explored using two different approaches. First, the use of fourteen different variables related to a country's general socio-economic situation, health, education, and services are utilized. The analysis is based on six different time periods 1990, 1995, 2000, 2005, 2010, and 2015. The variables included in the analysis refer to the 28 countries of the EU, namely: The Netherlands, Germany, Denmark, Ireland, Sweden, the United Kingdom, Luxembourg, Belgium, Austria, Finland, Slovenia, Italy, Spain, the Czech Republic, Greece, Cyprus, Estonia, Lithuania, Poland, Slovakia, Malta, Portugal, Hungary, Croatia, Latvia, Romania and Bulgaria. We calculate for each variable the time difference between the EU-28. The exact form of the modulation factor is as follows:

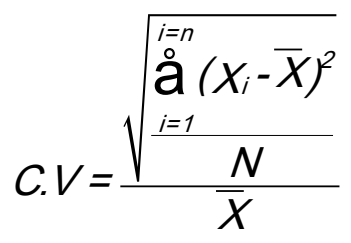

$X i$ is the value of each variable; $X$ is the average of the values of the variable; $n$ is the number of countries (i.e. EU-28), and $N$ is the number of observations. For each time period, and for each variable, a value of coefficient of variation is determined, which shows the evolution of the relative degree of inequality between the EU-28 countries. Reducing inequalities between countries occurs when the modulation factor is diminishing over time. When the coefficient of variation of all, or most of, the variables examined is decreasing, the result reveals that there is convergence between EU-28 countries. The coefficient of variation for the variables examined are shown in Table 2, while their evolution over time is shown in Figure 2. ${ }^{15}$ Figures 3 and 4 show the coefficient of variation for the same period, for the sub-group of Eurozone (EU-19) and PIIGSC (Portugal, Ireland, Italy, Greece, Spain, and Cyprus).

The problem with the above-mentioned classical approach to the quantification of inequalities between the EU-28 and EU-19 countries, is that it does not lead to conclusions if a significant part of the variables examined point in one direction (e.g. convergence) and the balance to another (e.g. deviation). For this reason, the empirical analysis at hand calculates and supports the conclusions on the average coefficient of differentiation of all variables (see Table 2).

15 This method has been used by Liargovas, G.Manolas, D.Giannias (1999). 
Table 2: Volatility indices for EU-28 member states.

\begin{tabular}{|c|c|c|c|c|c|c|}
\hline \multirow[t]{2}{*}{ Volatility Indices EU-28 } & \multicolumn{6}{|c|}{ VOLATILITY } \\
\hline & 1990 & 1995 & 2000 & 2005 & 2010 & 2015 \\
\hline $\begin{array}{l}\text { Population density (people per } \\
\text { sq. km of land area) }\end{array}$ & 1.3737 & 1.3399 & 1.3344 & 1.3715 & 1.3787 & 1.4122 \\
\hline $\begin{array}{l}\text { CO2 emissions (metric tons per } \\
\text { capita) }\end{array}$ & 0.4889 & 0.4041 & 0.4077 & 0.4589 & 0.4502 & 0.4729 \\
\hline Long-term unemployment & 0.3909 & 0.2776 & 0.3651 & 0.3169 & 0.3040 & 0.2786 \\
\hline $\begin{array}{l}\text { Mortality rate, under- } 5 \text { (per } \\
1.000 \text { live births) }\end{array}$ & 0.4771 & 0.5754 & 0.5960 & 0.5611 & 0.4945 & 0.4761 \\
\hline Physicians (per 1.000 people) & 0.2573 & 0.2209 & 0.2229 & 0.2137 & 0.2335 & 0.2539 \\
\hline $\begin{array}{l}\text { Mobile cellular telephone } \\
\text { subscriptions }\end{array}$ & 1.9620 & 1.2492 & 0.4743 & 0.1627 & 0.1466 & 0.1251 \\
\hline $\begin{array}{l}\text { Life expectancy at birth, total } \\
\text { (years) }\end{array}$ & 0.0362 & 0.0468 & 0.0394 & 0.0398 & 0.0371 & 0.0355 \\
\hline Internet users (per 100 people & 2.1187 & 1.3998 & 0.6442 & 0.3746 & 0.2074 & 0.1665 \\
\hline $\begin{array}{l}\text { Household final consumption } \\
\text { expenditure per capita (constant } \\
2005 \text { US\$ }\end{array}$ & 0.6072 & 0.6260 & 0.6025 & 0.5471 & 0.5205 & 0.4512 \\
\hline GDP per capita (current US\$) & 0.7837 & 0.7991 & 0.7388 & 0.6926 & 0.6600 & 0.6596 \\
\hline $\begin{array}{l}\text { Electric power consumption } \\
\text { (kWh per capita }\end{array}$ & 0.5923 & 0.6318 & 0.6099 & 0.5472 & 0.5460 & 0.4886 \\
\hline $\begin{array}{l}\text { School enrolment, primary (\% } \\
\text { gross) }\end{array}$ & 0.0856 & 0.0676 & 0.0531 & 0.0449 & 0.0421 & 0.0535 \\
\hline $\begin{array}{l}\text { School enrolment, secondary } \\
\text { (\% gross) }\end{array}$ & 0.1461 & 0.1756 & 0.1696 & 0.0898 & 0.0885 & 0.1570 \\
\hline Forest area (\% of land area) & 0.5430 & 0.5349 & 0.5278 & 0.5181 & 0.5108 & 0.5010 \\
\hline Coefficient of Variation (CV) & 0.7045 & 0.5963 & 0.4847 & 0.4242 & 0.4014 & 0.3951 \\
\hline
\end{tabular}

Source: own calculations 

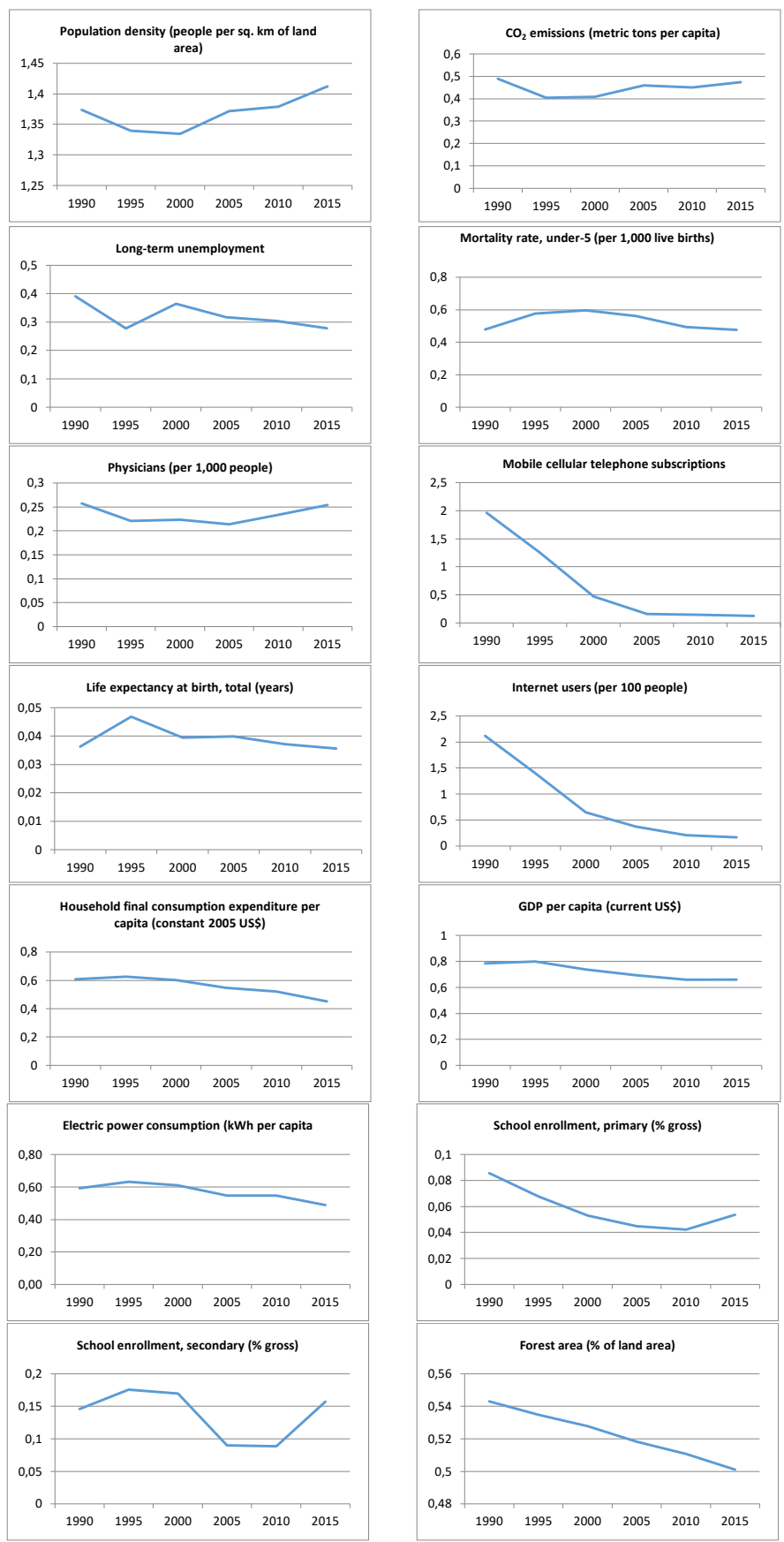

Figure 1: Volatility indices, 1990-2015 Analysing Convergence in EU-28 member states.

Source: own calculations. 

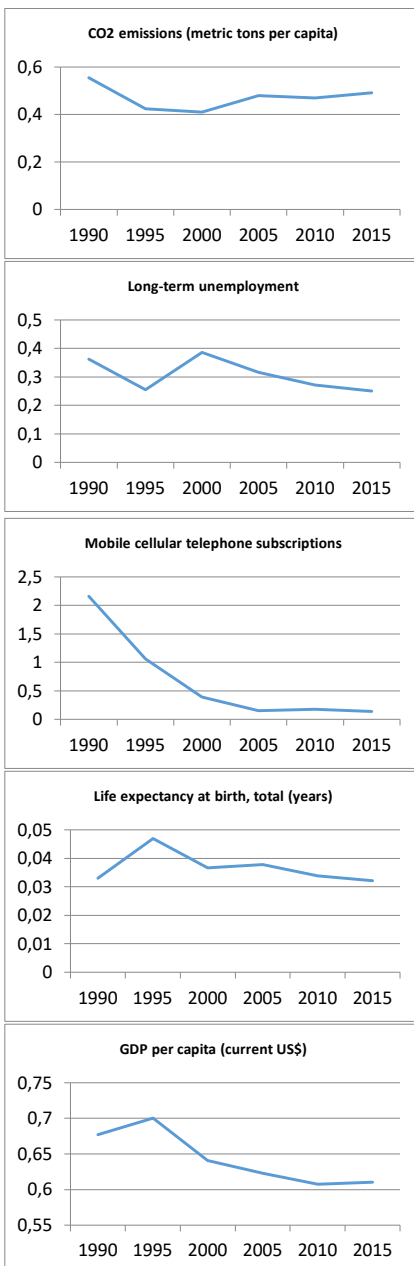

Electric power consumption (kWh per capita
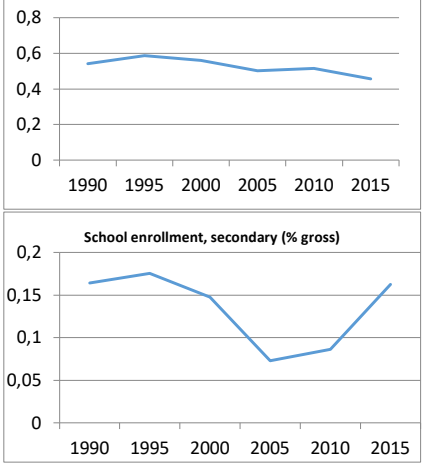

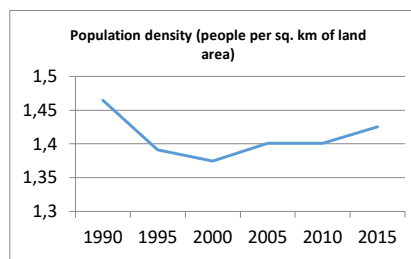

Mortality rate, under-5 (per 1,000 live births)

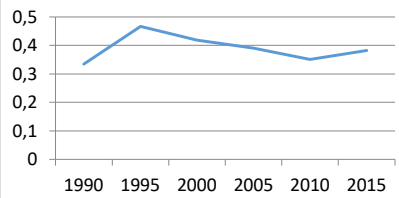

$199019952000 \quad 2005 \quad 20102015$

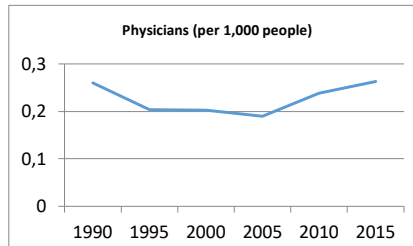

Internet users (per 100 people)

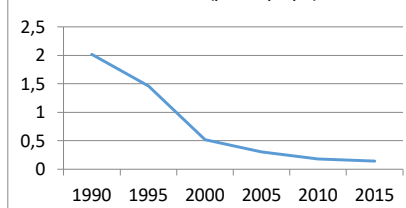

Household final consumption expenditure per capita (constant 2005 US\$

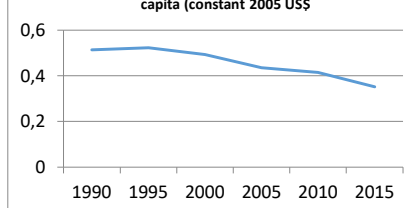

School enrollment, primary (\% gross)

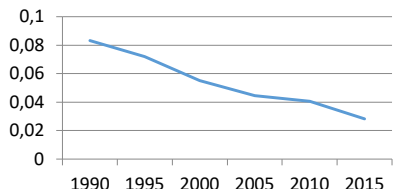

19952000200520102015

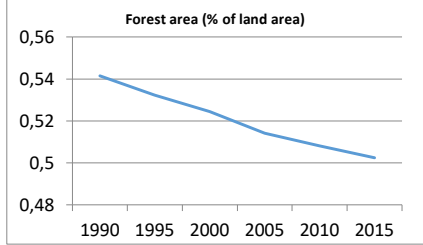

Figure 2: Volatility indices 1990-2015 Analysing Convergence in EU-19 Eurozone states. Source: own calculations. 


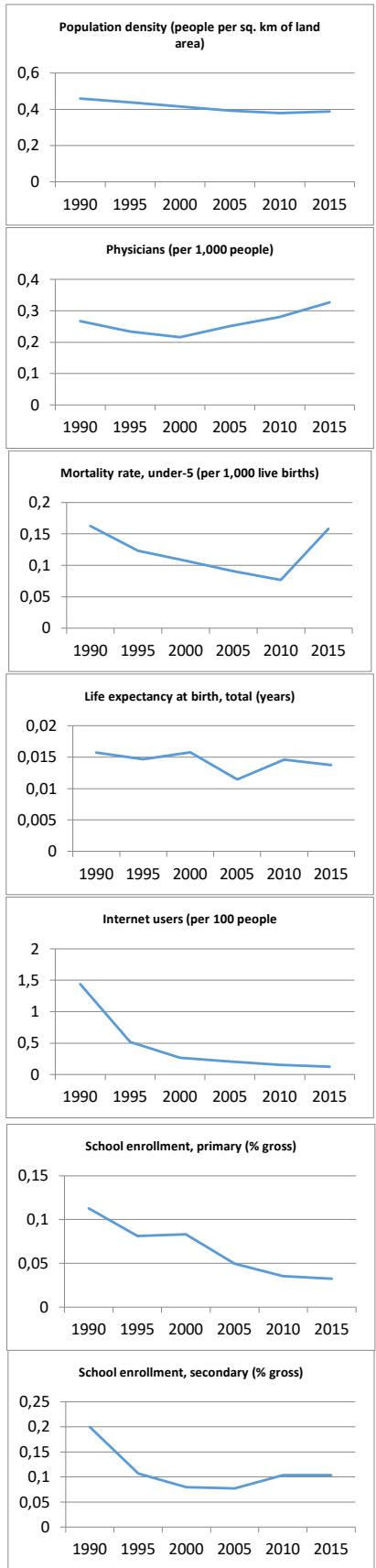

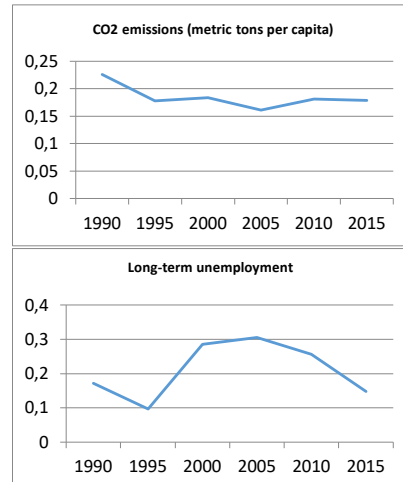
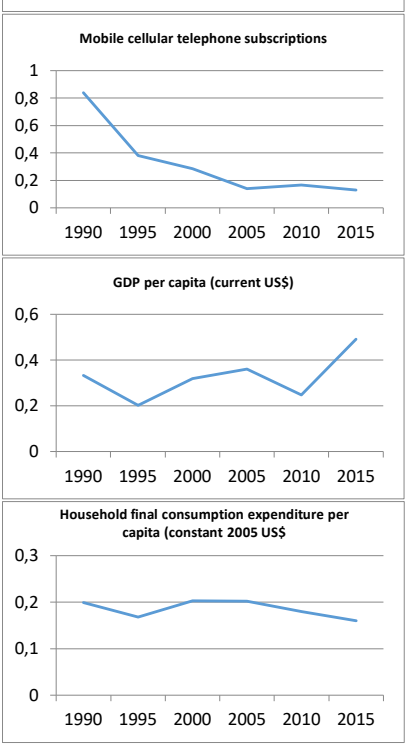

Electric power consumption (kWh per capita
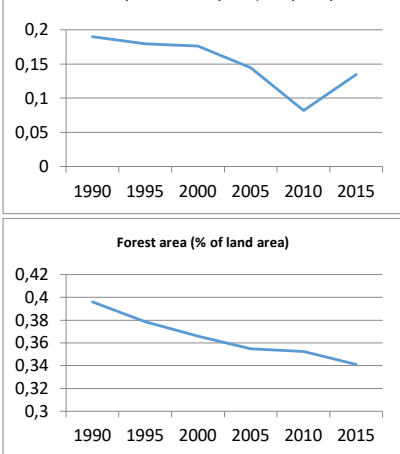

Figure 3. Volatility indices 1990-2015 Analysing Convergence in PIIGSC. Source: own calculations. 


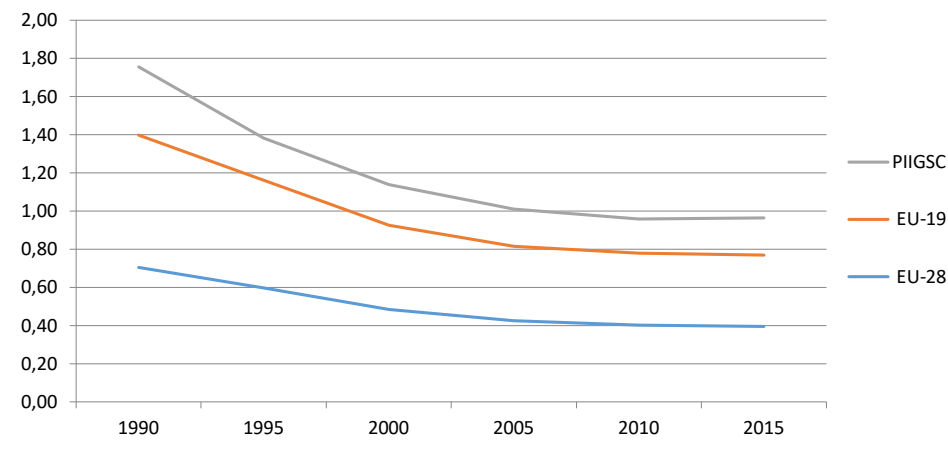

Figure 4: Average Volatility Indices 1995-2015 -various country groups.

Source: own calculations.

Related to the concept of convergence is the issue of disparities between EU countries and their evolution over time. The question of the temporal evolution of inequalities is investigated by country-ranking tables, based on the quality of life index. The quality of life index takes the following form:

$$
Q O L=\frac{\sum_{k=1}^{N}\left(w_{k} a_{k i}\right)}{\sum_{k=1}^{N}\left(w_{k j}\right)} \text { for } i=1,2,3, \ldots m
$$

Where,

$\alpha_{\mathrm{ki}}=$ the kth indicator of country $\mathrm{i}$

$\mathrm{w}_{\mathrm{k}}=$ the weights for the $\mathrm{k}$ indicator

$\mathrm{N}=$ the number of indcators considered

$\mathrm{m}=$ the number of countries being examined

The weights $w k$ can equal $1 / N$ or be assigned $a$ theoretically using principal component or survey results. It is worth pointing out that, in this investigation, the use of weights of individual variables has not been included with appropriate shaped questionnaires. Even so, it could be the subject of a future research. As is commonly established, people's needs and priorities have changed in recent years. As so, the specific weight of individual indicators may not remain stable, but change over the period of two decades. Likewise, this may be an element of the utmost importance for the quality of life in Southern European countries, which does not equally apply to improving the quality of life in Northern European countries due to the diversity of their needs. The quality of life index in a country is the middle value of the modified (scaled) variables. The modified value of a variable $X, X^{*}$ is between $0-100$ and is defined as follows:

$$
X^{*}=100(X-X \min ) /(X \max -X \min )
$$

Where $X$ is the value of the variables, and Xmin and Xmax are the minimum and maximum values respectively. $X^{*}$ is the modified value of the variable, only for 
variables that are positively related to the quality of life and $X^{*}=100-[100(X-X m i n)$ / (Xmax-Xmin)] for variables that are negatively related to the quality of life index (e.g. long-term unemployment, carbon dioxide emissions, population density, and mortality below 5 years). Results appear in Tables 3 and 4.

Table 3: Indices of Living Standards: Scaled index rating for the EU-28.

\begin{tabular}{|c|c|c|c|c|c|c|}
\hline & 1990 & 1995 & 2000 & 2005 & 2010 & 2015 \\
\hline Sweden & 1 & 1 & 1 & 2 & 1 & 1 \\
\hline Finland & 2 & 2 & 3 & 1 & 2 & 2 \\
\hline Austria & 3 & 5 & 5 & 5 & 4 & 4 \\
\hline Denmark & 4 & 3 & 7 & 4 & 5 & 5 \\
\hline France & 5 & 6 & 10 & 9 & 8 & 8 \\
\hline Netherlands & 6 & 7 & 4 & 6 & 7 & 10 \\
\hline Germany & 7 & 10 & 12 & 12 & 11 & 9 \\
\hline Belgium & 8 & 9 & 8 & 13 & 13 & 6 \\
\hline Luxembourg & 9 & 4 & 6 & 3 & 3 & 3 \\
\hline Italy & 10 & 12 & 9 & 10 & 10 & 11 \\
\hline Spain & 11 & 13 & 2 & 7 & 6 & 7 \\
\hline U.K & 12 & 14 & 13 & 8 & 22 & 23 \\
\hline Latvia & 13 & 27 & 26 & 22 & 20 & 20 \\
\hline Greece & 14 & 15 & 18 & 15 & 12 & 18 \\
\hline Lithuania & 15 & 16 & 21 & 20 & 16 & 16 \\
\hline Estonia & 16 & 22 & 17 & 17 & 17 & 14 \\
\hline Czech Republic & 17 & 17 & 19 & 19 & 15 & 17 \\
\hline Portugal & 18 & 11 & 11 & 14 & 14 & 21 \\
\hline Ireland & 19 & 18 & 14 & 11 & 9 & 12 \\
\hline Slovenia & 20 & 19 & 15 & 18 & 19 & 15 \\
\hline Slovakia & 21 & 23 & 22 & 23 & 24 & 24 \\
\hline Cyprus & 22 & 8 & 16 & 16 & 18 & 22 \\
\hline Croatia & 23 & 20 & 20 & 24 & 25 & 26 \\
\hline Bulgaria & 24 & 26 & 27 & 27 & 26 & 27 \\
\hline Malta & 25 & 21 & 24 & 25 & 27 & 19 \\
\hline Hungary & 26 & 24 & 23 & 21 & 23 & 25 \\
\hline Poland & 27 & 25 & 25 & 26 & 21 & 21 \\
\hline Romania & 28 & 28 & 28 & 28 & 28 & 28 \\
\hline
\end{tabular}

Source: own calculations 
Table 4: Countries with a higher, equal or lower Life Quality Index (ascending classification) EU-28.

\begin{tabular}{|c|c|c|c|c|c|}
\hline 1990 & 1995 & 2000 & 2005 & 2010 & 2015 \\
\hline $\begin{array}{l}\text { Countries with } \\
\mathrm{QOL}>\text { Average }\end{array}$ & $\begin{array}{l}\text { Countries with } \\
\text { QOL > Average }\end{array}$ & $\begin{array}{l}\text { Countries with } \\
\mathrm{QOL}>\text { Average }\end{array}$ & $\begin{array}{l}\text { Countries with } \\
\text { QOL > Average }\end{array}$ & $\begin{array}{l}\text { Countries with } \\
\mathrm{QOL}>\text { Average }\end{array}$ & $\begin{array}{l}\text { Countries with } \\
\text { QOL > Average }\end{array}$ \\
\hline Netherlands & Netherlands & Netherlands & Netherlands & Netherlands & Netherlands \\
\hline Germany & Germany & Germany & Germany & Germany & Germany \\
\hline Denmark & Denmark & Denmark & Denmark & Denmark & Denmark \\
\hline Sweden & Sweden & Sweden & Ireland & Ireland & Sweden \\
\hline $\begin{array}{l}\text { United } \\
\text { Kingdom }\end{array}$ & France & $\begin{array}{l}\text { United } \\
\text { Kingdom }\end{array}$ & Sweden & Sweden & France \\
\hline France & Luxembourg & France & $\begin{array}{l}\text { United } \\
\text { Kingdom }\end{array}$ & France & Luxembourg \\
\hline Luxembourg & Belgium & Luxembourg & France & Luxembourg & Belgium \\
\hline Belgium & Austria & Belgium & Luxembourg & Belgium & Austria \\
\hline Austria & Finland & Austria & Belgium & Austria & Finland \\
\hline Finland & Italy & Finland & Austria & Finland & Italy \\
\hline Italy & Spain & Italy & Finland & Italy & Spain \\
\hline Spain & Cyprus & Spain & Italy & Spain & \\
\hline \multirow[t]{2}{*}{ Latvia } & Portugal & Portugal & Spain & Greece & \\
\hline & & & Portugal & Portugal & \\
\hline $\begin{array}{l}\text { Countries with } \\
\mathrm{QOL}=\text { Average }\end{array}$ & $\begin{array}{l}\text { Countries with } \\
\text { QOL =Average }\end{array}$ & $\begin{array}{l}\text { Countries with } \\
\mathrm{QOL}=\text { Average }\end{array}$ & $\begin{array}{l}\text { Countries with } \\
\mathrm{QOL}=\text { Average }\end{array}$ & $\begin{array}{l}\text { Countries with } \\
\mathrm{QOL}=\text { Average }\end{array}$ & $\begin{array}{l}\text { Countries with } \\
\mathrm{QOL}=\text { Average }\end{array}$ \\
\hline Greece & $\begin{array}{l}\text { United } \\
\text { Kingdom }\end{array}$ & Ireland & Greece & & Ireland \\
\hline $\begin{array}{l}\text { Countries with } \\
\text { QOL < Average }\end{array}$ & $\begin{array}{l}\text { Countries with } \\
\text { QOL < Average }\end{array}$ & $\begin{array}{l}\text { Countries with } \\
\text { QOL <Average }\end{array}$ & $\begin{array}{l}\text { Countries with } \\
\text { QOL < Average }\end{array}$ & $\begin{array}{l}\text { Countries with } \\
\text { QOL < Average }\end{array}$ & $\begin{array}{l}\text { Countries with } \\
\text { QOL < Average }\end{array}$ \\
\hline Ireland & Ireland & Slovenia & Slovenia & $\begin{array}{l}\text { United } \\
\text { Kingdom }\end{array}$ & $\begin{array}{l}\text { United } \\
\text { Kingdom }\end{array}$ \\
\hline Slovenia & Slovenia & Czech Republic & Czech Republic & Slovenia & Slovenia \\
\hline Czech Republic & Czech Republic & Greece & Cyprus & Czech Republic & $\begin{array}{l}\text { Czech } \\
\text { Republic }\end{array}$ \\
\hline Cyprus & Greece & Cyprus & Estonia & Cyprus & Greece \\
\hline Estonia & Estonia & Estonia & Poland & Estonia & Cyprus \\
\hline Poland & Poland & Poland & Lithuania & Poland & Estonia \\
\hline
\end{tabular}


Continued Table 4: Countries with a higher, equal or lower Life Quality Index (ascending classification) EU-28.

\begin{tabular}{llllll}
\hline 1990 & $\mathbf{1 9 9 5}$ & $\mathbf{2 0 0 0}$ & $\mathbf{2 0 0 5}$ & $\mathbf{2 0 1 0}$ & $\mathbf{2 0 1 5}$ \\
\hline Lithuania & Lithuania & Lithuania & Slovakia & Lithuania & Poland \\
Slovakia & Slovakia & Slovakia & Malta & Slovakia & Lithuania \\
Malta & Malta & Malta & Hungary & Malta & Slovakia \\
Portugal & Hungary & Portugal & Croatia & Hungary & Malta \\
Hungary & Croatia & Hungary & Latvia & Croatia & Portugal \\
Croatia & Latvia & Croatia & Romania & Latvia & Hungary \\
Romania & Romania & Latvia & Bulgaria & Romania & Croatia \\
Bulgaria & Bulgaria & Romania & & Bulgaria & Latvia \\
& & Bulgaria & & & Romania \\
& & & & & Bulgaria \\
\hline
\end{tabular}

Source: own calculations

\subsection{Discussion}

Two statistical measures have been used to assess convergence and the evolutionary process of inequalities among EU-Member States between 1995 and 2015. Unlike previous studies, this research concentrates on measuring convergence in terms of a combination of economic and quality of life variables; indices that are consistent with the spirit of the Lisbon European Council and in accordance with the structural indices for nominated or real convergence between EU countries. The results of the first approach are presented in Figures $\mathbf{1}$ through $\mathbf{3}$ as well as in the Table 2, while the results of the second approach are presented in Tables $\mathbf{3}$ and $\mathbf{4}$.

More specifically, in examining Table 2, it is easy to conclude that, between 1990 and 2015, there is a low trend for convergence between EU-28. Inequalities have been reduced sufficiently since the average rate of coefficient of variation was 0.70454 , $0.59639,0.48475,0.424260 .40146$ and 0.3951 in the years $1995-2015$ respectively. The average coefficient of variation is constantly decreasing, which confirms the tendency for convergence. The conclusion remains the same for EU-19 (see Table 3). Figure 1 illustrates the changes in the coefficient of variation for the fourteen relevant variables for EU-28. First, the real convergence was achieved during the period 19902005 for all variables used in this study. For some of them, the process of convergence continued until 2010. This is the case for GDP per capita, primary, and secondary 
school enrolment for EU-28 ${ }^{16}$. Household final consumption expenditure per capita, mobile cellular telephone subscriptions, and forest area (\% of land area) converged even after 2015, not only for EU-28, but also for EU-19.

Second, it appears that disparities increased mostly after 2010. Disparities in the field of education (secondary school enrolment), in healthcare (physicians per 1,000 people), mortality rate, and population density increased after 2005. The evolution of disparities can be related to business cycles, and the global economic crisis. A number of arguments can be put forth to explain the idea that "convergence tends to dominate in periods of strong growth, and to recede in periods of stagnation". ${ }^{17}$

Third, since 1995, a decrease in economic and social disparities among Member States is detected, especially in the field of infrastructures (forest area and CO2 emissions), and communication (Internet users, mobile-cellular and telephone subscriptions), as well as in population density, long-term unemployment, physicians per 1000 people and primary school enrolment for EU-28, EU-19, and PIIGSC. GDP per capita shows a trend for convergence until 1995 only for PIIGS (the results are opposite to those of EU-28 and EU-19). ${ }^{18}$ However, monetary convergence was not achieved during the 1990s. Economic and social convergence can be attributed to the EU policies followed, especially after 1990. At the European Council of Brussels in February 1988, a decision was made to double the resources of the three structural funds (European Social Fund, European Regional Fund, FEOGA (guidance section)) and to change the Common Agricultural Policy. Additionally, the Delors Package was recognized as necessary for the successful implementation of the Internal Market programme.

The graph illustrating the average of the 14 variables reveals that inequalities and differences in quality of life between the 28 countries of Europe have declined throughout the 25 years-i.e. between 1990-2015-resulting in greater convergence between countries. This convergence appears to be more concentrated in the period between 2010-2015 in the field of infrastructures and in the field of economy and development not only for EU-28 but for EU-19. However, the indices for primary and secondary education, with a sharp divergence in 2015, are outlined. In reducing disparities, the policies of the European Union played a major role: First, in (a) agricultural policy with the main objective of increasing agricultural productivity, and thus ensuring a fair basic level in the agricultural sector, stabilizing markets and ensuring fair prices. Second, in (b) industrial policy so as to create competitive,

16 The results remain the same for EU-19, with exception the index secondary school enrolment where after 2015 there is a sharp divergence.

17 See Commission of the European Communities 1990, p. 216. However, recent results for the UK (for the period 1977-1991) suggest that this might not always be the case (Chatterji \& Dewhurst, 1996). 18 With the exception of the secondary school enrollment (\% gross), mortality rate, under-5 (per 1,000 live births), and life expectancy at birth. 
efficient, and targeted markets, favourable climate-especially for small and mediumsized enterprises - to promote research and development, networking, and business cooperation. Third, in (c) regional and economic policy of the European Union, where according to the preamble of the treaty establishing the EEC, it is a common concern for strengthening and ensuring harmonious development by reducing the differences between the various regions and achieving the development of backward and less favoured regions. This was one of the main reasons for the creation of the EEC decision. Fourth, (d) technological policy. The contribution of research and technology to regional development, as well as to the cohesion of the European community, has been highlighted many times. Community technology policy is directly aimed at enhancing the role of research competitiveness, comparing with US and Japan, as well as strengthening community cohesion and balancing regional differences between the Member States of the European Union. Fifth, and finally, the EU played a major role in e) the European Social Policy.

Table 3 shows the average of the rankings made based off of the modified value of the variables that affect the quality of life among the 28 countries of the European Union. It reveals that between 1990 and 2015, Nordic countries such as Sweden, Finland, Austria and Denmark were among the countries that possess the top five positions in terms of living standards. At the opposite end of the scale, Romania, Bulgaria, and Latvia occupy the last three positions. These figures do not show a uniform convergence movement between Southern and Northern European member states. The position of Greece shows deterioration, especially for the period between 1990-2005: where, ranking as $13^{\text {th }}$ in 1990 , it dropped to $15^{\text {th }}$ in 2005 . From then on, it continued to improve until 2010, where it held $12^{\text {th }}$ statically. In 2015 however, it dropped again to its lowest position at $18^{\text {th }}$, thus indicating a decrease in the quality of life index. Spain and Ireland, on the other hand, have significantly improved their positions respectively between 2000-2015.

Table 4 illustrates countries that have a higher than average quality of life index, equal, or less than average for each time period. Sweden ranks first for the whole period of the survey, with the exception of 2005, where it drops to $2^{\text {nd }}$ place after Finland, followed by Denmark, Austria, and Luxembourg. Contrastingly, Hungary, Malta, Croatia, Poland, Bulgaria and Romania are among the lowest. Greece between 1990 and 2005 presents an average life-quality index, while in the period 2015 it drops to lower than average. For the same period (1995), Cyprus and the UK also show a declining trend. This may be due to the economic crisis of 2008 and the painful austerity programs implemented. As reflected in the Eurofound report, entitled The quality of life in Europe: The impact of the crisis (2013), the EU witnessed a growing trend in unemployment rates, social exclusion, worsening social conditions, coupled with an increase in citizens' mistrust of public institutions, particularly governments and national parliaments reproached for being at the centre of political corruption. Understandably, all of this has led to increased social tension, both amongst racial 
groups as well as socio-economic classes. What was initially a financial crisis has, in some countries, given way to a social crisis.

One of the main consequences of the economic crisis is the high unemployment rate, particularly long-term and youth unemployment, which has had undoubtedly grievous ramifications on working conditions in Europe as a whole. It has also been particularly detrimental to certain aspects of society, including work-life balance. Even so, the impact of the crisis in the European Union has varied from country to country. The downturn in GDP, coupled with increasing unemployment, has taken its toll, particularly on Southern European countries such as Greece, Portugal, and Spain; although, certain northern European countries, such as Ireland, have also felt the backlash.

Convergence has also been assessed separately for the 19 member states (Eurozone), as well as for the PIIGSC countries ${ }^{19}$ and represented in Figures 2 and 3. These figures are similar to the previous graphs (Figure 1). The latter, however, are more intensified in terms of convergence, implying that EU regional policy has had some pertinent effects. Figures 2 and $\mathbf{3}$ contrastingly, show that EU-19 countries are more homogenous in terms of economic, monetary, and social indicators. A noteworthy pattern is also determined over time for the two groups in terms of residents enrolled in primary education. It is obvious that there is a strong trend for divergence for EU-28 countries in the period 2010-2015 (during the financial crisis), whilst the opposite is observed for EU-19 and PIIGSC during the same period. In comparison, there is a trend for convergence in the proportion of residents enrolled in secondary education for all the sub-groups in the same period.

There are many explanations for the increase in regional inequalities observed in Southern Europe in the second part of the 1990s. One factor involves the effects of trade liberalization as a result of the internal market programme. In the presence of increasing returns and agglomeration economies, such liberalization increased disparities between member states (Krugman \& Venables, 1990), where Southern Europe was negatively impacted by the process of trade liberalization across Europe. According to another explanation, there are structural differences between Southern and Northern European states and, therefore, the adjustment process is different. Blanchard et al. (1992) concentrate on production factor-movements and labour-movements in particular. They observe large and persistent disparities in employment growth across states. They also show that when regions are hit by negative shock, unemployment initially increases, leading to an exit of workers from the specific markets and regions. Accordingly, the difference between Northern and Southern regions could be attributed to different migration patterns due to increased unemployment rates in specific regions.

19 These are countries: Portugal, Italy, Ireland, Greece, Spain and Cyprus. 


\subsection{Conclusions}

The purpose of this study was to investigate convergence and test it empirically across countries of the EU between 1995 and 2015. Convergence was defined not only in terms of economic indicators, but also in terms of social and quality of life indicators. We computed real convergence by evaluating a coefficient of variation based on economic and quality of life variables. Given this convergence/divergence process, some countries may improve or worsen their position, relative to others. This was analysed by looking at the evolution of a quality-of-life-based ranking. It is confirmed that real convergence was achieved during the period 2005-2015 for most of the countries. Convergence stagnated in 1990-2000 before increasing again. We noticed that Sweden, Finland and Denmark occupy the top positions in quality of life index. Countries of Eastern and South-Eastern Europe place last in quality of life index.

This analysis may be an indispensable tool for European policy-makers to make significant financial resources available to apply appropriate economic policies in countries facing significant difficulties and lagging behind in a quality of life. This can lead to a broader redistributive policy community. The creators and designers of European Community policy should implement various financial assistance programs in order to achieve normalization of inequalities and to upgrade countries with low quality of life. This has the potential to eliminate regional disparities and imbalances both between member states and at a regional level, which in turn may prevent political tensions and frictions. Moreover, the analysis should be extended when additional data on the quality of life become available to determine whether our conclusions can be reconfirmed.

\section{References}

Blanchard, O. J., Katz, L. F., Hall, R. E., \& Eichengreen, B. (1992). Regional evolutions. Brookings Papers on Economic Activity, 1992(1), 1-75.

Bunyaratavej, K., Hahn, E. (2005). An Integrative Approach to Measuring Economic Convergence: The Case of the European Union. Global Economy Journal, 5(2), DOI:10.2202/1524-5861.1065

Chatterji, M., \& Dewhurst, J. L. (1996). Convergence clubs and relative economic performance in Great Britain: 1977-1991. Regional Studies, 30(1), 31-39.

Commission of the European Communities (1990). One Merket, One Money. European Economy, (44) October.

Giannias, D., Liargovas, P., \& Manolas, G. (1999). Quality of life indices for analysing convergence in the European Union. Regional Studies, 33(1), 27-35.

Henderson, C. (2001). How the Internet is changing our lives. The futurist, 35(4), 38.

Hobijn, B., \& Franses, P. H. (2001). Are living standards converging? Structural Change and Economic Dynamics, 12(2), 171-200.

Liargovas P., Fotopoulos G. (2008). Socioeconomic indicators for analyzing Convergence: the case of Greece: 1960-2004." Social Indicators Research, 93(2), 315-330. 
Marchante, A.J., Ortega B., Sánchez, J. (2006). The evolution of well-being in Spain (1980-2001): A regional analysis. Social Indicators Research, 76(2), 283-316.

Mazumdar, K. (2003). Do standards of living converge? A cross-country studySocial Indicators Research, 64(1), 29-50.

O'Donoghue, D. (2000). Some evidence for the convergence of employment structures in the British urban system from 1978 to 1991. Regional Studies, 34(2), 159-167.

O'Leary, E. (2001). Convergence of Living Standards Among Irish Regions: The Roles of Productivity, Profit Outflows and Demography, 1960-1996. Regional Studies, 35:3, 197-205.

Pack, J. R. (2004). Growth and convergence in metropolitan America: Brookings Institution Press.

Pinquart, M., \& Sörensen, S. (2000). Influences of socioeconomic status, social network, and competence on subjective well-being in later life: a meta-analysis: American Psychological Association.

Royuela, V., Artís, M. (2006). Convergence analysis in terms of quality of life in the urban systems of the Barcelona province, 1991-2000. Regional Studies, 40(5), 485-492 .

Royuela, V., García, G.,A. (2015). Economic and Social Convergence in Colombia. Regional Studies, 49:2, 219-239.Somarriba, N. (2008). Aproximación a la medición de la calidad de vida en la Unión Europea. Doctoral dissertation, Universidad de Valladolid). http://www. eumed. net/ tesis/2010/mnsa/index. htm.

Von Dem Knesebeck, O., Wahrendorf, M., Hyde, M., \& Siegrist, J. (2007). Socio-economic position and quality of life among older people in 10 European countries: results of the SHARE study. Ageing \& Society, 27(2), 269-284. 